Przegląd Narodowościowy / Review of Nationalities • nr 9/2019 - Sports as the expression of nation issues

sciendo

ISSN 2084-848X (print) • ISSN 2543-9391 (on-line) • DOI 10.2478/pn-2019-0010

\author{
Billy Graeff ${ }^{\star}$ \\ Federal University of Rio Grande, Brazil \\ https://orcid.org/0000-0001-8114-7829 \\ Daiana Viacelli Fernandes ${ }^{* *}$ \\ Anhanguera University in Rio Grande, Brazil \\ https://orcid.org/0000-0001-8464-0205
}

\title{
Continuity, change and rupture in Brazilian sport: reflections from the profile of the Ministers of Sport and the budget of the Ministry of Sport
}

\section{Introduction}

It is evident that sport has become an important element of contemporary society. Frequent media exposure and significant inclusion in the lives of people contribute to this importance to last and progress (Bourdieu, 1990a; Bourdieu, 1990b; Bourdieu, 1990c; Brohm, 1978; Dunning, 1992; Dunning, 2010; Elias, Dunning, 1985; Guttmann, 1978; Parker, 1976; Stigger, 2002). At the same time, sport has gained distinction in the economic and political context of many societies, at least since the late 80 s. In terms of political appeals to cities and nation-states to host mega-sport events, such as the men's soccer World Cup finals or the Summer Olympic Games, these events have gained increasing economic and political weight (Blake, Calvert, 2015; Horne, Manzenreiter, 2006; Roche, 1994; Roche, 2000).

In Brazil, sport has played an important social role for long time. However, this chapter cannot deepen this historic aspect. For now, we can only evidence how sport had its importance renewed from Lula's election as President and the development of the sport policy that brought to Brazil the men's football World Cup 2014 and the 2016 Summer Olympics. In this text, we analyze the period comprising the governments of Luiz Inácio Lula da Silva (2003-2006 and 2007-2010), Dilma Vana Rousseff (2011-2014 and 2015-2016) and Michel Temer (2016-2018).

The Workers Party, Lula's and Rousseff's political party, has developed activities together with a national sector of Sports and Leisure since 1998 (Castelan, 2011). However, since the election of Lula in 2002 and the composition of the Ministry of Sport with cadres of the Brazilian Communist Party and the Workers Party since 2003, sport has been gaining space in the political agenda of President Lula's coalition (the Popular Front). There is evidence of this mobilization around the National Sport Conferences (Presidency of the Republic, 2004) held in 2004, 2006 and 2010 (Souza, 2012; Araujo, 2013).

\footnotetext{
* Correspondence address: Federal University of Rio Grande - Av. Itália, s/n - Km 8 - Carreiros, Rio Grande, RS, Brasil, 96203-900, e-mail: billygraeff@furg.br.

** Correspondence address: Anhanguera University - Rio Grande - R. Mal, Floriano Peixoto, 510 - Centro, Rio Grande, RS, 96200-380, e-mail: daianaviacelli@gmail.com.
} 
Furthermore, the National Sport Conferences and their themes also support the view that the federal government led by the Workers Party took considerable steps in relation to sport (Pogrebinschi, Santos, 2011; Terra, 2009). It is important to note here that our narrative plays with the terms 'change, continuity and rupture' to try to establish relationships between broader events in the social and political spectrum and sport in Brazil, anchoring such analysis with the profiles of the Ministers of Sport and the budget of the Ministry of Sport in the $21^{\text {st }}$ century.

For example, the $1^{\text {st }}$ National Sport Conference in 2004 (Ministerio do Esporte, 2004) had the theme "Sport, Leisure and Human Development". It was the beginning of Lula's government and there was a flavour of change in the air. The theme of Lula's campaign had been "Hope Overcame Fear" ("A esperança venceu o medo", diz Lula em pronunciamento em SP, 2002). Sport was being discussed in the set of other areas. It was no longer just the domain of football club directors and representatives of competitive and elitist variants, it was part of an effort for human development.

In 2006 (Ministerio do Esporte, 2006), the $2^{\text {nd }}$ National Sport Conference had as its theme "Building the Sport National System". These conferences and their themes indicated a certain logic. During the first one, sport was discussed as part of a process of humanization. Then it evolved into a sport system that would provide such a process of human development. The Lula's government became professional, its staff began to operate from a more technical language.

In the period that followed, the focus of sport at the federal level shifted to megaevents, and the discussions in the context of the conferences lost their status, although they were not entirely ignored. However, in 2010 (Ministerio do Esporte, 2010), the $3^{\text {rd }}$ National Sport Conference, which received the title "For a Team Called Brazil", advanced in relativizing sport in the field of public policies. It is worth noting that the space for the contradictory, according to the title of the event, is also reduced. The debate begins to take place in a sphere of decision-making beyond the limits of the area of sport and the disputes begin to be located in high echelons of the government.

At the same time, sport perspectives that were represented in the political spectrum of the Brazilian left and the federal government began to collide. One of these perspectives was aimed at promoting sport as a right and via public policies. The other made efforts to bring to Brazil the Olympics and the World Cup. The latter also subsumed all sport area's efforts to such events. The consequences of the dominant sports policy at that time, that linked sport to mega events, will be better known when we study the profiles of Ministers and the budget of the Ministry of Sports in the period.

However, it is worth remembering that this moment was intensified from the 2013 Journeys of June. Several studies have been carried out to try and understand the explosion of criticism and public manifestations that have become common in Brazil since the so-called the June Journeys, which, among other things, led millions of people to the streets of Brazil, questioned the political agenda of country and highlighted issues 
until then far removed from the majority of the population (Charleaux, 2017; Teixeira, 2018). Here it is significant to point out that we are in the middle of the first Rousseff's government, which in a way was a continuation of Lula's government.

The June Journeys were public demonstrations that took place in Brazil between June and July 2013 (Medeiros, 2015). They began in large cities like São Paulo, Rio de Janeiro, Porto Alegre, Belo Horizonte and Salvador, among others, with demonstrations that attracted thousands of people. Later, the June Journeys spread through the streets of medium and small cities and also precipitated daily marches and meetings of hundreds of thousands of people in large cities and millions simultaneously in the country (Mendoça, 2017; Zoccal, 2017; Santos, 2015). According to several analyses, "there is no economic crisis or conjunctural problems that can serve as an explanation for [...] the manifestations" (Visentini, 2013), which excludes traditional explanations. And although there were allegations that the protests were too large and intuitive for rational understanding (Medina, 2013), it seems clear that the protests that have occurred on the streets of various cities around the world since the 2007-2008 economic crisis, in the context of what was called rebel cities, may have roots in the globalized policies of neoliberalism in terms of attacking social rights (Harvey, 2012).

It is relevant to report that, between 2009, when the host cities of the 2014 World Cup were chosen, and the year 2013, local resistance organisations remonstrating against the event (Popular World Cup Committees) and the National Articulation of the Popular World Cup Committees and the Olympiad were created (ANCOP) (Articulação Nacional dos Comitês Populares da Copa e das Olimpíadas, 2011; ComitePopularRio, 2011).

Explanations about the Journeys of June are still being developed and are part of the disputes related to the story that will be told. But it was in the context of such events that:

(1) The World Cup became a relevant theme in the country's main public discussions;

(2) Direct opposition to the event took shape;

(3) The expenses with the event began to be questioned in face of the social problems that affected the country;

(4) FIFA has become the target of more radical criticism.

These characteristics can be, although superficially, recognized in the images exhibited in the context of the June Journeys (Byrnes, 2013; Brazil World Cup protests, 2014; Downie, 2013; Nolan, 2013; Watts, 2013).

Slogans like "We want FIFA standard schools and hospitals" and "FIFA OUT" have become routine in the protests, as well as "Fuck the World Cup", "Fuck FIFA" and "FIFA go home" (Horne, Silvestre, 2016). Requests for foreign visitors not to go to Brazil during the World Cup period circulated on social networks and a video of a Brazilian who lives in the United States echoing that sentiment became viral (Guilherme Goncalves, 2013). Millions of people took to the streets in the June Journeys, and FIFA and the World Cup became targets of protest with Brazil hosting the Confederations Cup in the same month. The message from the streets was "There will be no world Cup" (Nãovaiter Copa, 2019). 
In this context, after the World Cup, a process of questioning the government, formed by Rousseff who had been re-elected in 2014, began. In 2016, the coup against the elected President took place. Temer (her Vice-President), who for months had been conspiring with opposition sectors, businessmen and members of his and other parties, assumed the presidency (Oliveira, 2016; Gaspari, 2016; Livros analisam e denunciam o golpe de 2016, 2016; Löwy, 2016; Ruffato, 2016). The coup narratives focused on corruption issues that the Workers Party, and the Left in general, would have created in the country. Economic, business, media and cultural elites supported the coup and Temer began a process of deepening elitist and neoliberal policies. Among the initial measures, Temer attacked the social sectors of the government, mainly in their financing (Governo corta benefícios ao exportador e reduz verba para projetos sociais para viabilizar diesel mais barato, 2018; Lima, 2016; Schreiber, 2016; Temer ataca direitos indígenas para tentar se livrar de denúncia no Congresso, 2017; Temer corta verba da educação, saúde, assistência social e saneamento, 2017). Sport did not escape (Castro, 2018; Drummond, 2018; Governo federal corta 87\% da verba para o Esporte em 2018, 2017).

Thus, this work analyzes the profile of the Ministers of Sport (Secretaria Especial do Esporte, 2019a) and the resources of the Ministry of Sports in the period between 2003 and 2018 to reflect on the consequences of these continuities, changes and ruptures for Brazilian sport.

\section{Methodology}

This chapter uses document analysis to discuss the consequences of social and political changes for Brazilian sports. Data sources for this work are news about the subjects studied and academic papers that present relevant information. Searches were performed on Google search engine looking for news, the terms used were "Budget Ministry Sport" and "Sport Ministers". In addition, the themes "Budget Sports Ministry" and "Sport Ministers" were searched in Google Scholar.

On the news of the Google search engine we found 13,000,000 results for the period January 1, 2003 and April 17, 2019, based on the theme "Sport Ministers". We selected 67 of these reports to support this work according to the saturation principle. With the theme "Sport Ministry budget", we found 6.17 million news, of which 32 were selected to support this work according to the saturation principle.

In Google Scholar, the term "Ministry of Sport budget" generated 25,500 references. Of these, 12 were selected to support this work. The term "Sport Ministers" generated 12,100 results in Google Scholar; 9 works from this list have been used in this chapter.

\section{Results}

The profile of the Ministers of Sport between 2003 and 2018 can provide clues about how sport was treated at each period of the federal governments of the Lula-Rousseff- 
Temer years. In order to analyze such profiles, a list of ministers is presented initially and then a discussion about their characteristics and the peculiarities of the periods in which their nominations were given (Secretaria Especial do Esporte, 2019b).

\section{Lula's government}

(1) Agnelo Queiroz (January 1, 2003 to March 31, 2006)

Physician, career politician by the Brazilian Communist Party. Studied sport to be a minister and was later accused of various irregularities. He took over the Ministry of Sport in January 2003. On March 31, 2006, he left office to run for the Senate (Agnelo Queiroz, 2019). Later, he moved to the Workers Party and today he is no longer involved in politics (Biografia Agnelo Queiroz, 2019).

(2) Orlando Silva (March 31, 2006 to October 26, 2011)

Lawyer, former president of the National Union of Students, known for being a good negotiator (Orlando Silva de Jesus Junior, 2019). So good that he won the arm wrestling with Queiroz to remain in the Ministry after assuming temporarily in his place. He resigned from the Ministry after allegations of undue expense on the corporate card. $\mathrm{He}$ returned the money and the accusations were never proven. Today he is a congressman for the Brazilian Communist Party (Biografia Orlando Silva, 2019).

\section{Rousseff's government}

(3) Aldo Rebelo (October 27, 2011 to January 1, 2015)

Journalist, career politician by the Brazilian Communist Party, came to replace Silva to give reliability to the Ministry. Rebelo has held several electoral positions throughout his career and was also minister in various ministries of governments of Lula-Rousseff. He was the face of the Federal Government in the organization of the World Cup (Alves, 2014) and personally supervised matters related to sport in the period (Aldo Rebelo é o novo Ministro do Esporte, 2011).

(4) George Hilton (January 1, 2015 to March 30, 2016)

Radio broadcaster and pastor, became a politician by the Social Liberal Party, then joining the Brazilian Republican Party (Matoso, 2016). When he took over, he himself came to express his lack of preparation for the job (Diniz, 2015). The minister had been known in the national media years before for being surprised at an airport with boxes full of cash, which would have been donated by his congregation.

\section{Temer's government}

(5) Ricardo Leyser Gonçalves (March 31, 2016 to May 12, 2016)

Ministry technician, who had been responsible for the Pan American Games 2007, was considered one of the more technical names of the Ministry of Sports and its repre- 
sentative for the Rio 2016 Olympic Games. He commanded the financing of the preparation of the Brazilian delegation to the Olympic Games and of the works of sports arenas (Interino Ricardo Leyser é o novo Ministro do Esporte, 2016).

(6) Leonardo Picciani (May 12, 2016 to April 9, 2018)

His passage through the Ministry was marked by many absences (Biografia Leonardo Picciani, 2019). He is from a family of politicians that faced various accusations during his period as a minister. Almost all of his political gurus are or have been arrested in the period surrounding his time as minister, including his father and brother (Lindner, 2018).

(7) Leandro Cruz (April 10, 2018)

The last minister to take over the Ministry, before it was transformed into the Special Secretariat of Sports, within the framework of the new Ministry of Citizenship (Secretaria Especial do Esporte, 2019b). He was the right arm of Picciani and this gives indications that suspicious things may have happened in Ministry of Sport as soon as Picciani came down under strong allegations of irregularities and fought much to leave the Ministry as inheritance to his associate who may have been able to, holding the position, delete tracks.

The budget of the Ministry of Sport also gives indications of how the issue was treated within the different governments. For example, when sport was used as a tool to achieve certain objectives, as discussed below, the budget of the Ministry tended to grow. On the other hand, to the extent that the Ministry appears to have been used as an element of negotiation between the forces of the government, such a budget tended to fall (Athayde et al., 2015; Canan et al., 2017; Mascarenhas, 2016):

(1) $2004 \$ 127,821,2$ million ( $\mathrm{R} \$ 457.6$ million);

(2) $2005 \$ 208,779.3$ million ( $\mathrm{R} \$ 747.43$ million);

(3) $2006 \$ 307,262.6$ million ( $\mathrm{R} \$ 1.1$ billion);

(4) $2007 \$ 769,776.9$ million ( $\mathrm{R} \$ 1.86$ billion);

(5) $2008 \$ 493,407.2$ million ( $\mathrm{R} \$ 1.48$ billion);

(6) $2009 \$ 847,910,6$ million ( $\$ 1.93$ billion);

(7) $2010 \$ 954,166,6$ million ( $\mathrm{R} \$ 2.29$ billion);

(8) $2011 \$ 1,237,5$ billion ( $\$ 2.97$ billion);

(9) $2012 \$ 475,558,3$ million ( $\mathrm{R} \$ 1.34$ billion);

(10) $2013 \$ 503,355.7$ million ( $\$ 1.86$ billion);

(11) $2014 \$ 769,776.9$ million (Sxhauteck et al., 2014); R 2.27 billion);

(12) 2015 \$714,997.6 million (Sxhauteck et al.; R 2.56 billion);

(13) $2016 \$ 1,185,321.5$ billion ( $\mathrm{R} \$ 4.38$ billion);

(14) 2017 \$441,112.8 million ( $\mathrm{R} \$ 1.63$ billion);

(15) 2018 undefined, but with at least an 87\% cut (Transparência no Esporte, 2019; Vecchiolli, 2017a). 


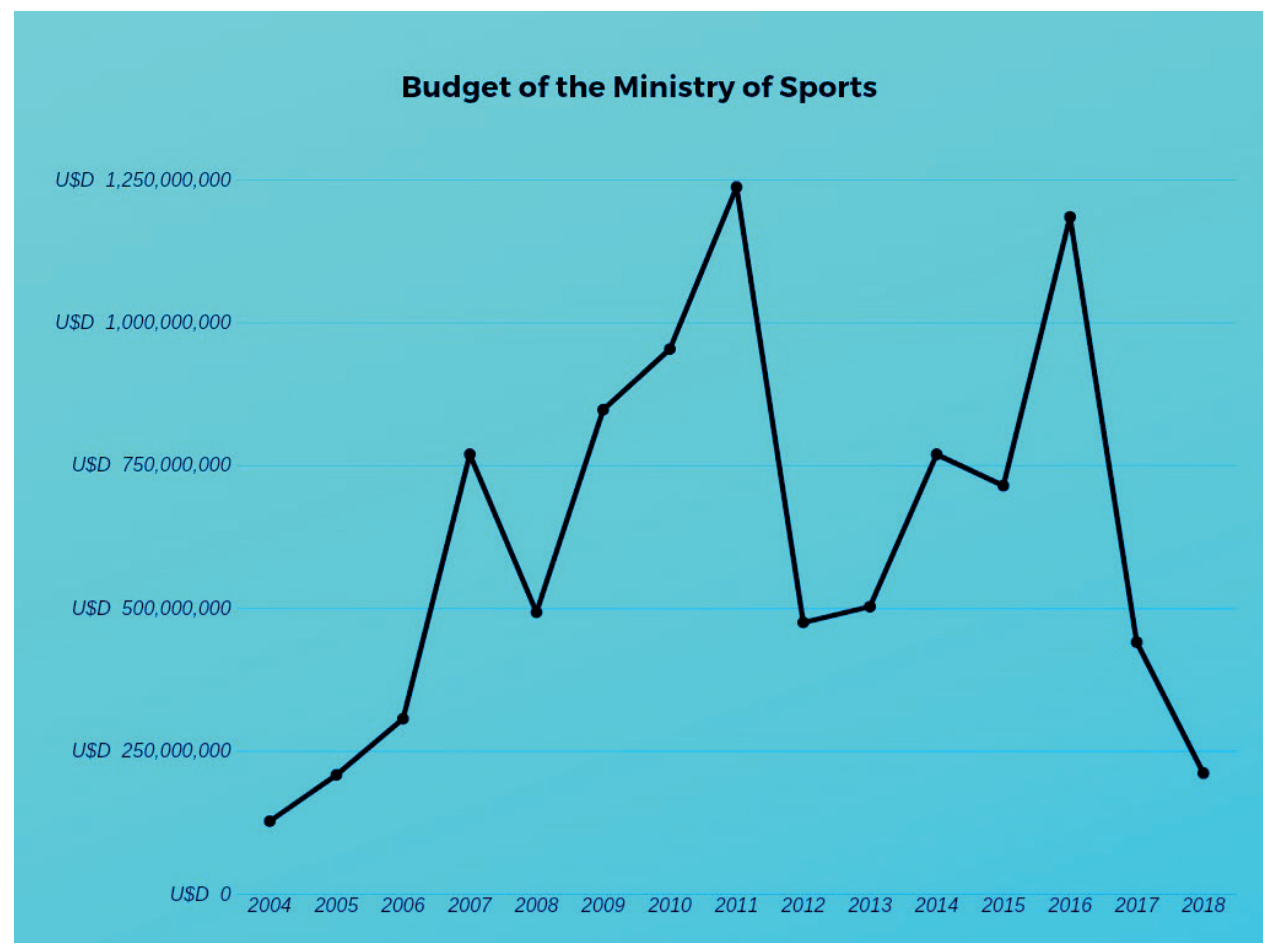

Graph 1. Budget of the Ministry of Sport Source: own elaboration.

\section{Discussion}

The general picture presented above enables some initial discussions on the role of the changes in sport politics in Brazil. However, it is necessary to make some considerations. First, the data used in the construction of the profiles of the ministers in the period covered can be complemented and their profiles and analysis of performance can be deepened. One should also take into account that during the period covered two of the largest global events were held in Brazil, the two biggest sporting events of contemporary times, the Football World Cup and the Summer Olympics. Certainly, these events influenced disputes for the Ministry of Sport, as well as the budget of that Ministry (Barros, 2016; Cruz, 2013; Vecchiolli, 2018; Lourenço, 2017; Ministério do Esporte terá um orçamento recorde em 2013, 2012). Reservations made, we can follow with what the data at the disposal allow.

On the profiles of the ministers and their relation to the general situation of the government before and during the coup, initially, it is important to note that the changes in the Ministry of Sport were not random. Both the Brazilian Communist Party and the 
Republican Brazilian Party, for example, when conquering the Ministry, made a turn to sport as a theme. The Brazilian Communist Party invested in various forms of training its members (Damiani, Silva, 2011; Moreira, 2011) and both the Republican Brazilian Party and the Brazilian Communist Party have occupied not only the Ministry of Sport in the Federal Government, but also secretaries of sport at state and municipal levels (Venceslau, 2014).

However, it is necessary to emphasize that from the beginning of the Lula's government until the end of the Temer's government, through the Rousseff's government, the profiles of the ministers has indeed changed. The ministers of the first governments of the Popular Front (Lula's government) held bond with the area and fostered participatory policies and clear decision-making processes. The ministers of Lula's second government and Temer's government were political figures not linked to sport. Above all, the most recent ministers have had their trajectory marked by scandals and corruption, and imprisonment of their family members are common occurrences in their political lives. That is, the changes in the political spectrum also reverberate in sport.

They also reverberated in the budget of the Ministry of Sport. For example, between 2003 and 2004, the first years of Lula's government, the budget increased by $63 \%$. Between 2007 and 2009, the budget continued to increase, in 2011 reaching almost 250\% increase compared to 2003. In 2016, the year of the Olympics in Rio de Janeiro, the budget reached almost ten times the value of the beginning of the period observed. In 2017, the first year of the Temer's government, the values fell by $60 \%$. 2018, the second and final year of the Temer's government, saw a cut of at least $87 \%$ in the sport budget as a whole in the federal government context.

The outlook for 2019 is devastating, with cuts expected to be even higher than those for 2018 (Ministério do Esporte reduz R\$ 478 milhões no orçamento para 2019, 2018), and the Ministry being extinguished and replaced for a secretary within the Ministry of Citizenship (Nomes do esporte se dizem preocupados com fim do ministério, 2018; Governo corta beneficios..., 2019). Temer's government made significant cuts in the budget of the Ministry and took the Ministry's budget to pre-mega events (Vecchiolli, 2017b) periods, which also heralds a period of precariousness of the area in the government that begins in 2019 .

\section{Conclusions}

The conclusions reached after the analyses highlighted in the previous sections is that the social and political changes in wider spheres affected the area of sport in Brazil. Evidence of this is (a) the decay associated with the Ministry's profiles, starting with the second government of Rousseff, but especially in the Temer's government (post-coup); and (b) cuts in the budget of the Ministry of Sport (since the coup to 2016, more sharply). 
Changes in the broader political context can explain the change in the profiles of the ministers over the study period, which will depend on more research in the area. Our analysis exposed that two groups of ministers could be identified during the period studied: those of Lula, markedly committed to the industry and with invested approaches to the area; and those from government Rousseff-Temer, who took actors unrelated with the area to the Ministry, without projects and from party negotiations only. If we refer to the title of the chapter, we could say that there was continuity among Lula's ministers, there was a change in the profile of the ministers when Rousseff's government took office, and there was a rupture when Temer performed the coup and became President.

The evidence associated with the Ministry's budget showed that there was an increase in the resources of the Ministry since the beginning of the Popular Front governments, prominently in the period of sport mega events. However, the data also revealed radical cuts in sport Ministry's budget from the second government of Rousseff, boosted by the government of Temer.

However, as said earlier, research in the area will be able to identify illuminating elements of such changes with respect to the wider context. For example, the Rousseff's government has been associated with public figures such as Katia Abreu (Venturini, 2016) and Joaquim Levy (Ayer, 2015), historically linked to sectors of the Brazilian right. Rousseff's own Vice-President, Temer, and his party, the Brazilian Democratic Movement, were some of the greatest articulators of the 2016 coup. Thus, there is room for continuity as narrative in the spectre of the coup, not just ruptures. But these discussions will not be possible in the context of this chapter, due to the scope and limits of space.

From this chapter, possibilities to deepen the analysis, based on the structure of this work, arise. It would be productive for the area, for example, to analyze in a deeper way the distribution of the total budget of the Ministry of Sport in the period among the several secretaries. This would also make it possible for the organization's impact on mega-sport events in the Ministry's budget to be better known. This would lead to a more effective evaluation of the movements related to the Ministry budget of the sport in the period.

An initial tool can be the Internet site Transparency in Sport(Transparência no Esporte, 2019). It is a portal with data relevant to the budget of sport in the country; it is organized by the research group Avante, University of Brasilia.

In addition, it will be positive if future research explores more closely the profile of sport ministers in the period and the context that led them to the Ministry. As a result of these studies, it would be productive that the movement of their nominations be inserted in the context of the surrounding actions of the political forces that sustained them throughout the temporal cut. For example, knowing what kind of actions and what kind of negotiations involved the nominations and policies implemented by ministers would contribute to elucidating their passages and their role in the area's development. 


\section{Bibliography}

"A esperança venceu o medo", diz Lula em pronunciamento em SP (2002), https://www1.folha.uol. com.br/folha/brasil/ult96u41584.shtml [access on: 8.02.2019].

Agnelo Queiroz (2019), https://ultimosegundo.ig.com.br/agnelo-queiroz/53ea200408ec508e570 000a3.html [access on: 11.04.2019].

Aldo Rebelo é o novo Ministro do Esporte (2011), https://www.gazetadopovo.com.br/vidapublica/aldo-rebelo-e-o-novo-ministro-do-esporte-a046cclqn96hg71wngzjurpe6/ [access on: 13.04.2019].

Alves J. (2014), Ministro do Esporte Aldo Rebelo garante que obras de estádios e de mobilidade urbana para Copa estão dentro do cronograma [Video file], https://www2.camara.leg.br/ camaranoticias/tv/materias/CAMARA-HOJE/426025-MINISTRO-DO-ESPORTE-ALDOREBELO-GARANTE-QUE-OBRAS-DE-ESTADIOS-E-DE-MOBILIDADE-URBANAPARA-COPA-ESTAO-DENTRO-DO-CRONOGRAMA.html [access on: 13.04.2019].

Araujo S.M. (2013), Conferências nacionais de esporte: o debate sobre controle social, VI Jornada Internacional de Políticas Públicas, http://www.joinpp.ufma.br/jornadas/joinpp2013/JornadaEixo2013/anais-eixo8-direitosepoliticaspublicas/conferenciasnacionaisdeesporteodebatesobrecontrolesocial.pdf [access on: 8.02.2019].

Articulação Nacional dos Comitês Populares da Copa e das Olimpíadas (2011), Dossiê Megaeventos e Violações dos Direitos Humanos no Brasil, http://www.apublica.org/wp-content/ uploads/2012/01/DossieViolacoesCopa.pdf [access on: 18.11.2018].

Athayde P., Mascarenhas F., Salvador E. (2015), Primeiras aproximações de uma análise do financiamento da política nacional de esporte e lazer no Governo Lula, "Revista brasileira de ciências do esporte”, No. 1(37), pp. 2-10, DOI: http://dx.doi.org/10.1016/j.rbce.2013.09.002.

Barros B. (2016), Comunidade esportiva defende recursos para o esporte e aprimoramento do Bolsa Atleta, http://www.brasil2016.gov.br/pt-br/noticias/comunidade-esportiva-defende-recursospara-o-esporte-e-aprimoramento-do-bolsa-atleta [access on: 2.05.2019].

Biografia Agnelo Queiroz (2019), https://www.camara.leg.br/deputados/73654/biografia [access on: 11.04.2019].

Biografia Leonardo Picciani (2019), https://www.camara.leg.br/deputados/74254/biografia [access on: 14.04.2019].

Biografia Orlando Silva (2019), https://www.camara.leg.br/deputados/178987/biografia [access on: 11.04.2019].

Blake H., Calvert J. (2015), The ugly game, London.

Bourdieu P. (1990a), Espaço simbólico e espaço social, [in:] Razões práticas: sobre a teoria da ação, edit. P. Bourdieu, São Paulo.

Bourdieu P. (1990b), Programme for a sociology of sport, [in:] Other Words, edit. P. Bourdieu, Cambridge.

Bourdieu P. (1990c), Programa para uma sociologia do esporte [in:] Coisas ditas, edit. P. Bourdieu, São Paulo.

Brazil World Cup protests: teenager dies as a million people take to the streets (2014), [Picture gallery], http://www.telegraph.co.uk/news/picturegalleries/worldnews/10133833/Brazil-World-Cupprotests-teenager-dies-as-a-million-people-take-to-the-streets.html [access on: 11.03.2019].

Brohm J. (1978), Partisans: Deporte, cultura y represión, Barcelona.

Byrnes M. (2013), 'We Don't Need the World Cup': Massive Protests Erupt Across Brazil, https:// www.citylab.com/equity/2013/06/we-dont-need-world-cup-stark-photos-brazils-enormousprotests/5942/ [access on:12.04.2019].

Canan F., Milani F.G., Starepravo F.A. (2017), Considerações sobre o 'fomento' ao esporte no Brasil, "The Journal of the Latin American Socio-cultural Studies of Sport", No. 1(8), pp. 74-88. 
Castelan L.P. (2011), As conferências nacionais do esporte na configuração da política esportiva e de lazer no Governo Lula (2003-2010), Dissertação (Mestrado em Educação Física), Universidade Estadual de Campinas.

Castro D.E. (2018), Corte de Temer no Bolsa Atleta atinge base e mantém verba para quem ganha mais, https://wwwl.folha.uol.com.br/esporte/2018/12/corte-de-temer-no-bolsa-atleta-atingebase-e-mantem-verba-para-quem-ganha-mais.shtml [access on: 14.04.2019].

ComitePopularRio (2011, December 6), A fala de Raquel Rolnik, Relatora da ONU para o Direito à Moradia, na Audiência Pública na Câmara Municipal do Rio de Janeiro sobre o legado social dos megaeventos [Video file], https://www.youtube.com/watch?v=H7FhX_J9XzM [access on: 18.11.2018].

Cruz J. (2013), Ministério do Esporte gasta apenas 20\% do orçamento deste ano, https://josecruz. blogosfera.uol.com.br/2013/12/ministerio-do-esporte-gasta-apenas-20-do-orcamento-desteano/ [access on: 13.05.2019].

Charleaux J.P. (2017), O que foram, afinal, as Jornadas de Junho de 2013. E no que elas deram, "Nexo", 18.06.2017, https://www.nexojornal.com.br/expresso/2017/06/17/O-que-foram-afinalas-Jornadas-de-Junho-de-2013.-E-no-que-elas-deram [access on: 15.01.2019].

Damiani C., Silva O. (2011), O esporte e o projeto de desenvolvimento para o Brasil, [in:] Políticas Públicas para um novo projeto nacional de desenvolvimento: a experiência dos comunistas, edit. M. Scádua, São Paulo.

Diniz F. (2015), Hilton: posso não entender de esporte, mas entendo de gente, “Terra”, 2.01.2015, https://www.terra.com.br/noticias/brasil/politica/hilton-posso-nao-entender-de-esportemas-entendo-de-gente,ca6dc310beaaa410VgnVCM4000009bcceb0aRCRD.html [access on: 14.04.2019].

Downie A. (2013), Brazil's World Cup Protests Intensify as Country's Politicians and FIFA Squirm, “Time”, 21.06.2013, http://world.time.com/2013/06/21/brazils-world-cup-protests-intensifyas-countrys-politicians-and-fifa-squirm/ [access on: 12.04.2019].

Drummond I. (2018), A reação ao corte de verbas do governo Temer para o esporte, "Estado de Minas", 14.06.2018, https://www.em.com.br/app/noticia/politica/2018/06/14/interna politica,966709/a-reacao-ao-corte-de-verbas-do-governo-temer-para-o-esporte.shtml [access on: 12.04.2019].

Dunning E. (1992), A dinâmica do desporto moderno: notas sobre a luta pelos resultados e o significado do desporto, [in:] A busca da excitação: Memória e sociedade, edit. N. Elias, E. Dunning, Lisboa.

Dunning E. (2010), Figurational/process-sociological reflections on sport and globalization: some conceptual-theoretical observations with special reference to the 'soccer' form of football, "European Journal for Sport and Society”, No. 3-4(7), pp. 183-194, DOI: https://doi.org/10.108 $0 / 16138171.2010 .11687856$.

Elias N., Dunning E. (1985), A Busca da Excitação, Lisboa.

Gaspari E. (2016), O que vem a ser o golpe de 2016, "Globo", 31.08.2016, https://oglobo.globo.com/ opiniao/o-que-vem-ser-golpe-de-2016-20021641 [access on: 14.05.2018].

Governo corta benefícios ao exportador e reduz verba para projetos sociais para viabilizar diesel mais barato (2018), https://oglobo.globo.com/economia/governo-corta-beneficios-ao-exportadorreduz-verba-para-projetos-sociais-para-viabilizar-diesel-mais-barato-22735721 [access on: 15.04.2019].

Governo federal corta 87\% da verba para o Esporte em 2018 (2017), https://www.correiodopovo. com.br/esportes/governo-federal-corta-87-da-verba-para-o-esporte-em-2018-1.241596 [access on: 11.03.2019].

Guilherme Goncalves (2013, June 18), Carla won't go to world cup [Video file], https://www. youtube.com/watch?v=tQwayUVccaw [access on: 30.05.2019]. 
Guttmann A. (1978), From ritual to record: the nature of modern sports, New York.

Harvey D. (2012), Rebel cities, New York.

Horne J., Manzenreiter W. (2006), An introduction to the sociology of sports mega events, "The Sociological Review", No. 8(54), pp. 1-24, DOI: https://doi.org/10.1111/j.1467-954X.2006.00650.x.

Horne J., Silvestre G. (2016), Brazil, Politics, the Olympics and the FIFA World Cup, [in:] The Routledge Handbook of Sport and Politics, edit A. Bairner, J. Kelly, J. Woo Lee, London.

Interino Ricardo Leyser é o novo Ministro do Esporte (2016), http://globoesporte.globo.com/ olimpiadas/noticia/2016/03/interino-ricardo-leyser-e-confirmado-como-novo-ministro-doesporte.html [access on: 14.04.2019].

Lima J. (2016), Temer ataca toda educação e põe em risco ampliação de vagas nas escolas, "Esquerda Diario", 25.05.2016, https://www.esquerdadiario.com.br/Temer-ataca-toda-educacao-e-poeem-risco-ampliacao-de-vagas-nas-escolas [access on: 10.04.2019].

Lindner J. (2018), Maioria de aliados de Temer não se elegem, "Estado de S.Paulo", 8.10.2018, https:// politica.estadao.com.br/noticias/eleicoes,diante-de-impopularidade-do-governo-maioria-dealiados-e-ex-ministros-de-temer-nao-se-elege,70002539342 [access on: 14.04.2019].

Livros analisam e denunciam o golpe de 2016 (2016), https://www.redebrasilatual.com.br/cultu$\mathrm{ra} / 2016 / 08 /$ livros-analisam-e-denunciam-o-golpe-de-2016-6892/ [access on: 13.04.2019].

Lourenço L. (2017), Gasto do Ministério do Esporte com diárias cresce 70\% em ano olímpico, "Globo", 15.02.2017, http://globoesporte.globo.com/sp/olimpiadas/noticia/2017/02/gasto-doministerio-do-esporte-com-diarias-cresce-70-em-ano-olimpico.html [access on: 14.04.2019].

Löwy M. (2016), O golpe de Estado de 2016 no Brasil, “Carta Maior”, 1905.2016, https://www. cartamaior.com.br/?/Editoria/Politica/O-golpe-de-Estado-de-2016-no-Brasil/4/36139 [access on: 12.04.2018].

Mascarenhas F. (2016), O orçamento do esporte: aspectos da atuação estatal de FHC a Dilma, "Revista Brasileira de Educação Física e Esporte”, No. 4(30), pp. 963-980, DOI: https://doi. org/10.1016/j.rbce.2018.03.032.

Matoso F. (2016), Planalto anuncia saída de George Hilton do Ministério do Esporte, "Globo", 30.03.2016, http://g1.globo.com/politica/noticia/2016/03/planalto-anuncia-saida-de-georgehilton-do-ministerio-do-esporte.html [access on: 13.04.2019].

Medeiros J. (2015), Breve história das jornadas de junho: uma análise sobre os novos movimentos sociais e a nova classe trabalhadora no Brasil, "Revista História \& Perspectivas", No. 27(51).

Medina C. (2013), New protests, old paradigms, "Matrizes”, No. 2(7), pp. 37-47.

Mendonça R.F. (2017), Dimensões democráticas nas jornadas de junho: reflexões sobre a compreensão de democracia entre manifestantes de 2013, "Revista Brasileira de Ciências Sociais", No. 33(98), pp. 1-23, DOI: https://doi.org/10.1590/339707/2018.

Ministerio do Esporte (2004), I Conferência Nacional do Esporte, http://www2.esporte.gov.br/ conferencianacional/conferencia1.jsp [access on: 11.04.2019].

Ministerio do Esporte (2006), II Conferência Nacional do Esporte, http://www2.esporte.gov.br/ conferencianacional/conferencia2.jsp [access on: 11.04.2019].

Ministerio do Esporte (2010), III Conferência Nacional do Esporte, http://www2.esporte.gov.br/ conferencianacional/conferencia3.jsp [access on: 11.04.2019].

Ministério do Esporte reduz R\$ 478 milhões no orçamento para 2019 (2018), https://maquinadoesporte.uol.com.br/artigo/ministerio-do-esporte-reduz-r-478-milhoes-no-orcamentopara-2019_35405.html [access on: 8.02.2019].

Ministério do Esporte terá um orçamento recorde em 2013 (2012), https://veja.abril.com.br/esporte/ ministerio-do-esporte-tera-um-orcamento-recorde-em-2013/ [access on: 13.04.2019]. 
Moreira D. (2011), Recife Bom de Bola: Copa do Mundo e Legado Esportivo, [in:] Políticas Públicas para um novo projeto nacional de desenvolvimento: a experiência dos comunistas, edit. M. Scádua, São Paulo.

Nãovaiter Copa (2019), https://www.facebook.com/NaoVaiTerCopa/ [access on: 12.04.2019].

Nolan S. (2013), The World Cup riots: One million Brazilians protest at government spending $£ 18$ billion on tournament, “The Daily Mail”, 21.06.2013, https://www.dailymail.co.uk/news/ article-2345600/Brazil-riots-One-million-protest-government-spending-18billion-WorldCup.html [access on: 12.04.2019].

Nomes do esporte se dizem preocupados com fim do ministério (2018), https://www.diariodocentrodomundo.com.br/essencial/nomes-do-esporte-se-dizem-preocupados-com-fim-do-ministerio/ [acess on: 13.05.2019].

Oliveira T.B. (2016), O golpe de 2016: breve ensaio de história imediata sobre democracia e autoritarismo, "Historiae", No. 2(7), pp. 191-232.

Orlando Silva de Jesus Junior (2019), http://www.fgv.br/cpdoc/acervo/dicionarios/verbetebiografico/orlando-silva-de-jesus-junior [access on: 11.04.2019].

Parker S. (1976), The sociology of leisure, London.

Pogrebinschi T., Santos F. (2011), Participação como representação: o impacto das conferencias nacionais de politicas publicas no congresso nacional, "Revista de Ciências Sociais", No. 3(54), pp. 259-305.

Presidency of the Republic (2004), Decreto de 21 de janeiro de 2004. Institui a Conferência Nacional do Esporte e dá outras providências, http://www.planalto.gov.br/ccivil_03/_Ato2004-2006/2004/ Dnn/Dnn10107.htm [access on: 12.04. 2019].

Roche M. (2000), Mega events and modernity, London.

Roche R. (1994), Mega events and Urban Policy, "Elsevier - Annals of Tourism Research”, No. 1(21), pp. 1-19.

Ruffato L. (2016), O golpe contra Dilma Rousseff. O afastamento da presidenta é sem dúvida o capítulo mais vergonhoso da história política brasileira, "El Pais", 1.09.2016, https://brasil.elpais. com/brasil/2016/08/31/opinion/1472650538_750062.html [access on: 11.04.2019].

Santos V.C.C. (2015), Juventude e política: jornadas de junho e manifestações em Brasília, Monografia (Bacharelado em Ciências Sociais), Universidade de Brasília.

Schreiber M. (2016), O que mudou com Temer nos programas sociais como o Bolsa Família, "BBC", 17.11.2016, https://www.bbc.com/portuguese/brasil-37991062 [access on: 11.04.2019].

Secretaria Especial do Esporte (2019a), http://www.esporte.gov.br/ [access on: 21.04.2019].

Secretaria Especial do Esporte (2019b), Ministerio Institucional, http://www.esporte.gov.br/ index.php/institucional/o-ministerio/publicidade/52-ministerio-do-esporte/institucional/oministerio/historico [access on: 14.04.2019].

Schausteck de Almeida B., Marchi Júnior W. \& Pike E. (2014), The 2016 Olympic and Paralympic Games and Brazil's soft power, "Contemporary Social Science: Journal of the Academy of Social Sciences", 9:2, 271-283, DOI: 10.1080/21582041.2013.838291.

Souza C.H.L. (2012), A que vieram as conferências nacionais? Uma análise dos objetivos dos processos realizados entre 2003 e 2010, Brasilia.

Stigger M. (2002), Esporte, Lazer e Estilos de Vida: um estudo etnográfico, Campinas.

Teixeira D.B. (2018), As jornadas de junho de 2013 e a crise da democracia, "Instituto Humanitas Unisinos", 11.07.2018, http://www.ihu.unisinos.br/78-noticias/580737-as-jornadas-de-junhode-2013-e-a-crise-da-democracia [access on: 26.01.2019].

Temer ataca direitos indígenas para tentar se livrar de denúncia no Congresso (2017), https://www. socioambiental.org/pt-br/noticias-socioambientais/temer-ataca-direitos-indigenas-paratentar-se-livrar-de-denuncia-no-congresso [access on: 13.04.2019]. 
Temer corta verba da educação, saúde, assistência social e saneamento (2017), https://www.brasil247. $\mathrm{com} / \mathrm{pt} / 247 /$ brasil/335902/Temer-corta-verba-da-educa\%C3\%A7\%C3\%A3o-sa\%C3\%BAdeassist\%C3\%AAncia-social-e-saneamento.htm [access on: 14.04.2019].

Terra A.M. et al. (2009), As conferências nacionais do esporte: avanços e limites na construção de políticas de esporte e lazer, Congresso Brasileiro de Ciências do Esporte and Congresso Internacional de Ciências do Esporte, http://www.rbceonline.org.br/congressos/index.php/ CONBRACE/XVI/paper/view/775/806 [access on: 20.04.2019].

Transparência no Esporte (2019), Ferramenta de monitoramento e visualização gráfica dos recursos públicos do esporte na esfera federal produzida e atualizada pelo Grupo de Pesquisa e Formação Sociocrítica em Educação Física, Esporte e Lazer da Universidade de Brasília, o Avante-UnB, http://www.transparencianoesporte.unb.br/?fbclid=IwAR0QUB9BhU2FWs58tdezHOLzXa MP5eIlDUxUkLEiiUL56gXeqQtIRqLMaQ\#/inicio [access on: 16.04.2019].

Vecchiolli D. (2017a), Governo corta 87\% do orçamento do Ministério do Esporte para 2018, "Folha de S.Paulo", 19.09.2017, https://www1.folha.uol.com.br/esporte/2017/09/1919798-governocorta-87-do-orcamento-do-ministerio-do-esporte-para-2018.shtml [access on: 14.04.2019].

Vecchiolli D. (2017b), Orçamento do Esporte proposto por Temer volta ao nível de 2010, "UOL", 16.11.2017, https://olharolimpico.blogosfera.uol.com.br/2017/11/16/orcamento-do-esporteproposto-por-temer-volta-ao-nivel-de-2010/?cmpid=copiaecolahttps://olharolimpico. blogosfera.uol.com.br/2017/11/16/orcamento-do-esporte-proposto-por-temer-volta-aonivel-de-2010/ [access on: 14.05.2019].

Vecchiolli D. (2018), Se esporte deu passo a frente com Olimpíada, MP de Temer dá 2 passos atrás, "UOL", 12.06.2018, https://olharolimpico.blogosfera.uol.com.br/2018/06/12/se-esporte-deupasso-a-frente-com-olimpiada-mp-de-temer-da-2-passos-atras/ [access on: 12.05.2019].

Venceslau P. (2014), Além de ministério, PRB ganha pastas estaduais de Esporte, https://exame.abril.com. $\mathrm{br} / \mathrm{brasil} / \mathrm{alem}$-de-ministerio-prb-ganha-pastas-estaduais-de-esporte/ [acess on: 13.05.2019].

Visentini P. (2013), Editor's note: Brazil, the weakest link of brics?, "Revista Brasileira de Estratégia e Relações Internacionais", No. 4(2).

Watts J. (2013), Brazil's protests raise fears for World Cup as a million take to the streets, "The Guardian”, 21.06.2013, https://www.theguardian.com/world/2013/jun/21/brazil-protestsfootball-world-cup [access on: 12.02.2019].

Zoccal M.P. (2017), Jornadas de junho de 2013: a cidade como palco dos novos movimentos sociais de protesto brasileiros, "Revista Eletrônica da Faculdade de Direito de Franca", No. 1(12), pp. 317-335, DOI: https://doi.org/10.21207/1983.4225.356.

\begin{abstract}
This chapter discusses the continuities, changes and ruptures in Brazilian sport from the profiles of the Ministers of Sport and the budget of the Ministry of Sport from 2003 to 2018. For that, we identify the sport in a social panorama that includes President Luiz Inácio Lula da Silva's election, the choice of Brazil to host the 2014 World Cup and the Olympics 2016, the 2013 June Journeys and the 2016 coup. Data are presented on the profile of the Ministers and the resources of the Ministry of Sports in the period between 2003 and 2018 to assist a reflection on the different political and social moments the country went through in the period. The conclusions after the analysis indicated that such changes affected sport in Brazil and that more research is needed to clarify the extent of such modifications and its consequences.
\end{abstract}

Keywords: sociology of sports, sport mega events, Brazilian sport, global capitalism 